Www.jmscr.igmpublication.org Impact Factor 5.84

Index Copernicus Value: 83.27

ISSN (e)-2347-176x ISSN (p) 2455-0450

crossref DOI:_https://dx.doi.org/10.18535/jmscr/v5i3.74

Journal Of Medical Science And Clinical Research

\title{
Effectiveness of Imparting Education and Giving Demonstration in Small Group of Women for Promotion of Breast Self Examination: An Experience in Rural Areas of Jaipur District, Rajasthan
}

\author{
Authors \\ Manju Singhi ${ }^{1}$, Mradula Singh ${ }^{2}$, Shalu Gupta ${ }^{3}$, A K Dixit ${ }^{1 *}$ \\ ${ }^{1}$ Desert Medicine Research Centre (ICMR), New Pali Road, Jodhpur , 342003 \\ ${ }^{2}$ Model Rural Health Research Unit (DHR), Bhanpur Kalan,Jaipur \\ ${ }^{3} \mathrm{~S}$ M S Medical College, Jaipur \\ Email: singhimanju58@gmail.com,dixitstat@rediffmail.com \\ *Corresponding Author \\ A K Dixit \\ Desert Medicine Research Centre (ICMR), New Pali Road, Jodhpur, 342003
}

\begin{abstract}
Effectiveness of imparting education and giving demonstration in small groups of women for promotion of Breast Self Examination: An experiance in rural areas of Jaipur district, Rajasthan.

Abstract-Breast cancer is a major Public health concern and a leading cause of morbidity and mortality among women (14.3\%). With the rising incidence of breast cancer and absence of any uniform Breast screening strategy, it is important to impart the knowledge and promote BSE practice among women. The present paper aims to study the effectiveness of imparting education and giving demonstration in small group of women for promotion of Breast Self Examination for early detection of the breast cancer and the factors which hinders with the uptake of the technique and what could be planned to improve the current scenario for its sustainability. The present study was undertaken in Model Rural Health Research Unit, Department of Health Research, Government of India at Bhanpur Kalan, Jaipur, Rajasthan in the year 2015-16 among 595 women (20-65 years age). Results have shown that overall knowledge of breast cancer and about sign \& symptoms of the disease was increase to $97.78 \%$ from $4.11 \%$ initial knowledge and $89.41 \%$ women started doing BSE practice. Enhanced Knowledge and awareness of BSE practice resulted in the detection of early sign and symptoms by the women in the study group. Study results have shown BSE as one of the most feasible, sustainable, cost freee, simple and non-invasive intervention carried out by the women themselves in early detection of breast cancer. Results derived from these studies will help the program managers and healthcare professionals to modify and strengthen the existing strategies so that the greatest challenge of late presentation can be minimized.
\end{abstract}

Keywords: Breast cancer, Breast self-examination, sign \& symptoms \& awareness. 
Breast cancer among women is a major concern today. It is a leading cause of morbidity and mortality among women ${ }^{1-4}$ in developed and developing countries due to late diagnosis and medical expenditures ${ }^{5}$. Trend analysis showed 50$100 \%$ rise in cases of breast cancer during last 20 years ${ }^{6}$. Breast cancer account for $19.3 \%$ of all cancer among women in India. India reports 100,000 new cases annually and 1 in 26 women are expected to be diagnosed with breast cancer in their life time. As there is no etiological agent for breast cancer, early diagnosis and treatment is of prime inportantance in improving the morbidity and mortality status of women. However, reports show that most of the women are still not aware about breast cancer ${ }^{7}$. Breast cancer is diagnosed at later stages in India due to poor knowledge, lack of awareness and BSE practice among women. Breast self examination(BSE),clinical breast examination(CBE) and memography are the available techniques to screen breast cancer8. Clinical Breast Examination and memography require hospital visit, speciaized equipments and technical expertise, whereas, BSE is a simple, feasible, non-invasive, cost free and can be carried out by women themselves. In developing countries reports have shown that BSE is one of the feasible and effective approach in early detection of breast cancer9. Number of studies have shown that women who regularly perform BSE have rare involvement of axillary lymphnode10.Under the scenerio, Breast self examination becomes an important method that can be done by every woman with little training to them. From India very few studies have been reported to demonstrate impact of breast cancer awareness at community level.

In the absence of any established national screening program for breast cancer; particularly in rural areas this becomes important. The present study is to derive experiences of educating and demonstrating BSE to rural population in district Jaipur, Rajasthan towards our efforts of making BSE a routine practice among the women. For limited availability of Medical \& para medical health staff in the rural areas, it becomes important to train ANM,s, health workers and women about the BSE practice. For early detection of breast cancer, it is important to educate women for detection of early sign and symptoms of the disesase with regular practice of BSE . The present study aims to assess the impact of imparting knowledge about sign ,symptoms and practice of breast self examination among rural women ,for early detection of breast cancer.

The present study was executed in Model rural Health Research Unit, Department of Health Research, Goverment of India at Bhanpur Kalan, Jaipur, Rajasthan in the year 2015-16. Three villages of Jamvaramgarh block of Jaipur district i.e. Bhanpur Kalan, Papad and Chawand Ka Mand having population $>2500$ were selected. A total of 595 women (20-65 years of age) were enrolled in the study. The women in were divided into three groups, reproductive age i.e. $20-30$ years, middle age $31-45$ years and older age $46-65$ years. Written informed consent was obtained from women after explaining the study objectives and assuring the confidentiality and privacy of the data obtained. This study was approved by the Institutional ethical committee. During the study period ANM , ASHA sahyogni and women were educated about disease, its sign \& symptoms thorough educational material, posters and charts and were demonstrated for Breast self examination. The training sessions were conducted in small group of 8-10 women. Women were taught the mirror method for visual insepection of breast and lying down position for breast palpation. Women were advised to inspect for any sign and symptoms of breast cancer and to do self examination, initially on daily basis for the first month and then on weekly basis so as to familarize them for the method. Thereafter, once a month examination was advised as per their manustral cycle. The education was followed by interactive session with the investigator to clearify their doubts. After 45 days, their knowledge about sign \& symptoms of breast cancer was evaluated by 10 point questionnaire and BSE 
practice by 5 points questionnaire. Two followups were done each at an interval of 45 days. Columns 10-12 of table-1 show, on an average $4.11 \%$ of initial knowledge about sign \& symptoms of the disease among rural women, which has increased to $83.29 \%$ after intervention (imparting education) in Ist follow up and to $97.78 \%$ in 2 nd follow up. Initially $0.4 \%$ women knew about shrink in of nipples, groove formation, change in size /shape of breast, after impating knowledge about individual sign \& symptoms of disease it became $94.7 \%, 96.7 \%$ \& $98.1 \%$ respectively, only $0.7 \%$ women knew about secretion /discharge from nipples, change in nipple position, redness of skin \& development of red patches, after intervention, it increased to 99.5 $\%, 98.1 \%, 99.0 \%$ \& $99.5 \%$ respectively. Initially $4.2 \%$ women were aware about pain in arm pit after intervention it became $99.5 \%$, Whereas, pain in breast was known to $15.8 \%$ women \& lump in breast was known to $18.3 \%$ women, which increased to $99.5 \%$ \& $100 \%$ respectively.

Age wise, over all awareness about sign \& symptoms in the age group 20-30 years was 4.23 $\%, 4.87 \%$ in the age group $31-45$ years, \& 2.54 $\%$ in the age group of 46-65 years After imparting knowledge in the 1 st and 2nd follow ups, the knowledge increased significantly from $4.2 \%$ to $83.7 \&$ to $98.46 \%$ in $20-30$ years age group from $4.87 \%$ to $84.58 \%$ \& to $97.7 \%$ in $31-45$ years age group; whereas in age group age 46-65 years it increased from $2.54 \%$ to $79.30 \%$ \& to $96.25 \%$. As such the women in the age group of 31-45 years were found to be more receptive as compared to other age group.

Table-2 shows overall and age wise awareness about BSE practice among rural women. Initially only $0.16 \%$ women were found familarized with the Breast Self Examination and used to do practice whereas after imparting education $65.47 \%$ women in 1 st follow up \& $89.41 \%$ women in the 2 nd follow up started BSE practice.

BSE practice in different age groups has shown that only $0.35 \%$ women were aware in the age group 20-30 years initially, after imparting knowledge $65.52 \%$ women started doing BSE in the I st follow up \& $89.47 \%$ women in the 2 nd follow up, initial $0 \%$ knowledge was observed in the age group 31-45 years, after Ist follow up it increased to $72.78 \%$ \& in 2 nd follow up it increased to $91.72 \%$, In age group 46-65 year shown $0 \%$ initial knowledge which increased to $51.76 \%$ in Ist follow up and after 2nd follow up it increased to $84.38 \%$.

Enhanced Knowledge and awareness of BSE practice among rural women helped in the detection of early sign and symptoms of breast cancer in 9 women by themselves all these subjects were motivated to approach medical college for clinical diagnosis and treatment where one of the co-author took all necessary care in this regard.

Breast cancer is a global health concern and a leading cause of morbidity and mortality among women. In India breast cancer is now at top among all cancers among the women and its incidence is rising steeply11. About $72 \%$ of India, population is residing in the rural areas. Health of women and her access to health facility is further compromised due to socio-cultural, economical and environmental factors thus emphasising a need to educate them about disease $\&$ motivate them for early detection of cancer. WHO12 reported that burden of the cancer can be reduced by imparting the knowledge about the disease. Therefore, it is very important to provide assistance to educate the women and make them aware about disease, its sign \& symptoms and promote practice of BSE among them. This study was undertaken to educate women and demonstrate BSE to make routine practice for early detection of breast cancer among women residing in rural areas of Rajasthan.

Total 595, women of the age group 20-65 years were educated about breast cancer, its sign \& symptoms and BSE practice with the help of health workers for its sustainability.

Educating and giving demonstration of BSE to rural women in small groups of 8-10 women has 
yielded good results. As we note from table-1, Initialiy mere $4.11 \%$ knowledge about breast cancer among rural women, increased to $83.29 \%$ in Ist follow up and further to $97.78 \%$ in 2 nd follow up. It is also noted from this table that 4.23 $\%$ initial knowlege in the age group of 20-30 years has increased to $83.71 \%$ and further to $98.46 \%$ in 2 nd follow up of the study, $4.87 \%$ Initial knowledge in the age group 31-45 years has increased to $84.58 \%$ and further to $97.78 \%$, and in the age group of 46-65\% initial knowledge of $2.54 \%$ increased to $79.40 \%$ and further to $96.25 \%$. This amounts to say that all the women irrespective of their age were receptive to gain knowledge about breast cancer, even the women in the older age group. This was unique observation contrary to the notion that women in the older age group may not be that equally receptive as women in the younger age group in rural areas. As regards to BSE, this was noted from table-2 that in the age group of 20-30 years, initially $0.35 \%$ women were aware about BSE, which has increased to $89.47 \%$ in 2 nd follow up, in the age group of 31-45 years, initial knowledge increased from $0 \%$ to $91.72 \% \&$ in the age group of 45-65 years increased from $0.16 \%$ to $89.41 \%$. It is intresting to note from here that middle age group women were more particular to do BSE practice as compared to 46-65 years of age. Though $\%$ increase of BSE practice in younger group was also good but less than the middle age group, older women showed less intrest in doing BSE practice. This may be because that in the context of rural setup, older age women were not finding a proper place to underatke BSE.

During the study period increased knowledge of rural women about breast cancer could revealed an occurence of sign \& symptoms in $1.65 \%$ women. This clearly supports the importance of BSE for early detection by women themselves.

Breast self examination practice is considered to be an important tool in the early detection of breast cancer inspite of few barriers such as lack of time, fear of possible detection, feeling of awkwardness about breast handeling, forgetfulness and poor accesibility of health care system and lack of motivational support by family members. Inspite of such reported barries in our study BSE practice has increased to $89.4 \%$ from $0.16 \%$. It was also noted that barriers can be minimized by the involvment of grass root health workers and involment of community, specially old pepople, husband and the influencing member of the family as to understand the importance of BSE. The knowledge and training given to health workers will helpful in sustainability of BSE practice. where the health workers will educate women regularly and motivate them for BSE. practice

The results of this study suggest that in rural areas of Rajasthan though the knowledge about breast cancer and practice of BSE is meager among the women but intervention in small groups can lead to useful results in the early detection of disesase which may be taken by health planners in their programme on early detection of breast cancer in the state as a whole.

\section{Acknowledgements}

The authors acknowledge ASHA Sahyogni and Anganwadi workers who helped in obtaining the data and the participants. The author also greatful to the Director, DMRC Jodhpur for providing the necessary facilities \& funds. 
Table 1: Awareness about the sign \& symptoms of breast cancer

\begin{tabular}{|c|c|c|c|c|c|c|c|c|c|c|c|c|}
\hline Sign \& & & $\begin{array}{c}\text { Age Group } \\
\text { 20-30 years }\end{array}$ & & & $\begin{array}{r}\text { Age Grou } \\
31-45 \text { yea }\end{array}$ & & & $\begin{array}{l}\text { Age Grou } \\
46-65 \text { yea }\end{array}$ & & & Total & \\
\hline & $\begin{array}{c}\text { Initial } \\
\text { visit } \\
(1) \\
\end{array}$ & $\begin{array}{c}1^{\text {st }} \text { Follow } \\
\text { up } \\
(2)\end{array}$ & $\begin{array}{c}2^{\text {nd }} \\
\text { Follow up } \\
\text { (3) }\end{array}$ & $\begin{array}{c}\text { Initial } \\
\text { visit } \\
(4)\end{array}$ & $\begin{array}{c}1^{\text {st }} \text { Follow } \\
\operatorname{up}_{(5)}\end{array}$ & $\begin{array}{c}2^{\text {nd }} \text { Follow } \\
\text { up } \\
(6)\end{array}$ & $\begin{array}{l}\text { Initial } \\
\text { visit } \\
(7)\end{array}$ & $\begin{array}{c}1^{\text {st }} \text { Follow } \\
\text { up } \\
(8)\end{array}$ & $\begin{array}{c}2^{\text {nd }} \text { Follow } \\
\text { up } \\
\text { (9) }\end{array}$ & $\begin{array}{c}\text { Initial } \\
\text { visit } \\
(10)\end{array}$ & $\begin{array}{c}1^{\text {st }} \text { Follow } \\
\text { up } \\
(11)\end{array}$ & $\begin{array}{c}2^{\text {nd }} \text { Follow } \\
\text { up } \\
(12)\end{array}$ \\
\hline & $\begin{array}{c}\mathrm{N}=284 \\
(\%)\end{array}$ & $\mathrm{N}=232(\%)$ & $\begin{array}{c}\mathrm{N}=209 \\
(\%)\end{array}$ & $\begin{array}{c}\mathrm{N}=197 \\
(\%)\end{array}$ & $\begin{array}{c}\mathrm{N}=158 \\
(\%)\end{array}$ & $\begin{array}{c}\mathrm{N}=133 \\
(\%)\end{array}$ & $\begin{array}{c}\mathrm{N}=114 \\
(\%)\end{array}$ & $\mathrm{N}=85(\%)$ & $\mathrm{N}=64(\%)$ & $\begin{array}{c}\mathrm{N}=595 \\
(\%)\end{array}$ & $\begin{array}{c}\mathrm{N}=475 \\
(\%)\end{array}$ & $\begin{array}{c}\mathrm{N}=406 \\
(\%)\end{array}$ \\
\hline Lump in breast & $52(18.3)$ & $228(98.3)$ & 209 (100) & $\begin{array}{c}40 \\
(20.3)\end{array}$ & $158(100)$ & $133(100)$ & $14(12.3)$ & $84(98.8)$ & $64(100)$ & $\begin{array}{c}106 \\
(17.8)\end{array}$ & $471(99.2)$ & $406(100)$ \\
\hline $\begin{array}{l}\text { Secretion/ } \\
\text { Discharge from } \\
\text { nipple }\end{array}$ & $2(0.7)$ & $191(82.3)$ & 208 (99.5) & $2(1)$ & 131(82.9) & $129(96.9)$ & $1(0.9)$ & $66(77.6)$ & $62(96.9)$ & $5(0.8)$ & $388(81.7)$ & 399(98.3) \\
\hline $\begin{array}{l}\text { Shrink in of } \\
\text { nipples }\end{array}$ & $1(0.4)$ & $135(58.2)$ & 198 (94.7) & 0 & $96(60.8)$ & $126(94.7)$ & 0 & $40(47.1)$ & $59(92.2)$ & $1(0.2)$ & $271(57.1)$ & 381(93.8) \\
\hline $\begin{array}{l}\text { Groove/ } \\
\text { Puckering/ } \\
\text { dimpling }\end{array}$ & $1(0.4)$ & $139(59.9)$ & $202(96.7)$ & 0 & $93(58.9)$ & $128(96.2)$ & 0 & $44(51.8)$ & $59(92.2)$ & $1(0.2)$ & $276(58.1)$ & $387(95.3)$ \\
\hline $\begin{array}{l}\text { Change in } \\
\text { nipple position }\end{array}$ & $2(0.7)$ & 173 (74.6) & $205(98.1)$ & 0 & $111(70.3)$ & $129(96.9)$ & 0 & $50(58.8)$ & $58(90.6)$ & $2(0.3)$ & $334(70.3)$ & 391(96.3) \\
\hline Pain in breast & $45(15 . .8)$ & $230(99.1)$ & 208 (99.5) & $39(19.8)$ & 157(99.4) & 131(98.5) & $11(9.6)$ & $84(98.8)$ & $64(100)$ & $95(16)$ & $472(99.4)$ & 403(99.3) \\
\hline Pain in armpit & $12(4.2)$ & $226(97.4)$ & 208 (99.5) & $13(6.6)$ & 157(99.4) & 132(99.2) & $3(2.6)$ & 83(97.6) & $64(100)$ & $28(4.7)$ & $467(98.3)$ & 404(99.5) \\
\hline $\begin{array}{l}\text { Change in } \\
\text { shape/size }\end{array}$ & $1(0.4)$ & $192(82.8)$ & $205(98.1)$ & $1(0.5)$ & $130(82.3)$ & $128(96.2)$ & 0 & $66(77.6)$ & $60(93.8)$ & $2(0.3)$ & $388(81.7)$ & 393(96.8) \\
\hline Redness of skin & $2(0.7)$ & 207 (89.2) & 207(99) & $1(0.5)$ & 148(93.7) & $132(99.2)$ & 0 & $77(90.6)$ & $63(98.4)$ & $3(0.5)$ & 432(90.9) & 402(99) \\
\hline Red patches & $2(0.7)$ & $221(95.3)$ & 208 (99.5) & 0 & $155(98.1)$ & $133(100)$ & 0 & $81(95.3)$ & $63(98.4)$ & $2(0.3)$ & $457(96.2)$ & 404(99.5) \\
\hline $\begin{array}{l}\text { On an aver- } \\
\text { age } \quad(\%)\end{array}$ & 4.23 & 83.71 & 98.46 & 4.87 & 84.58 & 97.78 & 2.54 & 79.40 & 96.25 & 4.11 & 83.29 & 97.78 \\
\hline
\end{tabular}

Table 2- Breast Self Examination practice in different age groups

\begin{tabular}{|c|c|c|c|c|}
\hline $\begin{array}{l}\text { Age group } \\
\text { (years) }\end{array}$ & Frequency of doing BSE & $\begin{array}{c}\text { Initial practice } \\
(\%)\end{array}$ & $\begin{array}{l}\text { After I }{ }^{\text {st }} \text { follow up } \\
\text { practice }(\%)\end{array}$ & $\begin{array}{c}\text { After } 2^{\text {nd }} \text { follow up } \\
\text { practice }(\%)\end{array}$ \\
\hline $20-30$ & $\begin{array}{c}\text { once/day } \\
\text { once/week } \\
\text { once/month }\end{array}$ & $\begin{array}{c}(\mathrm{n}=284) \\
0(0 \%) \\
0(0 \%) \\
1(0.35 \%)\end{array}$ & $\begin{array}{c}(\mathrm{n}=232) \\
20(8.6 \%) \\
77(33.1 \%) \\
55(23.70 \%)\end{array}$ & $\begin{array}{c}(n=209) \\
22(10.52 \%) \\
87(41.62 \%) \\
78(37.32 \%)\end{array}$ \\
\hline $\begin{array}{ll}\text { Total } & \text { respondent } \\
\text { undertaken } & \text { BSE } \\
\end{array}$ & & $1(0.35 \%)$ & $152(65.52 \%)$ & $187(89.47 \%)$ \\
\hline $31-45$ & $\begin{array}{c}\text { once/day } \\
\text { once/week } \\
\text { once/month }\end{array}$ & $\begin{array}{c}(\mathrm{n}=197) \\
0(\%) \\
0(0 \%) \\
0(0 \%)\end{array}$ & $\begin{array}{c}(\mathrm{n}=158) \\
19(12.02 \%) \\
54(34.17 \%) \\
42(26.58 \%)\end{array}$ & $\begin{array}{c}(\mathrm{n}=133) \\
9(6.76 \%) \\
76(57.14 \%) \\
37(27.82 \%)\end{array}$ \\
\hline $\begin{array}{ll}\text { Total } & \text { respondent } \\
\text { undertaken } & \text { BSE } \\
\end{array}$ & & $0(0 \%)$ & $115(72.78 \%)$ & $122(91.72 \%)$ \\
\hline $46-65$ & $\begin{array}{c}\text { once/day } \\
\text { once/week } \\
\text { once/month }\end{array}$ & $\begin{array}{c}(\mathrm{n}=114) \\
0(\%) \\
0(0 \%) \\
0(0 \%)\end{array}$ & $\begin{array}{c}(\mathrm{n}=85) \\
7(8.24 \%) \\
17(20 \%) \\
20(23.52 \%)\end{array}$ & $\begin{array}{c}(n=64) \\
6(9.37 \%) \\
20(31.25 \%) \\
28(43.75 \%)\end{array}$ \\
\hline $\begin{array}{ll}\text { Total } & \text { respondent } \\
\text { undertaken } & \text { BSE }\end{array}$ & & $0(0 \%)$ & $44(51.76 \%)$ & $54(84.38 \%)$ \\
\hline $\begin{array}{l}\text { Overall \% of women } \\
\text { who under took BSE }\end{array}$ & & $0.16 \%$ & $311(65.47 \%)$ & $363(89.41 \%)$ \\
\hline
\end{tabular}




\section{References}

1. Althuis, M.D., Dozier, J.M., Anderson, W.F., Devesa, S.S. and Brinton, L.A, "Global trends in breast cancer incidence and mortality 1973-1997, Int J Epidemiol, 34 (2), 405-12, 2005.

2. Shibuya, K., Mathers, C.D., Boschi-Pinto, C., Lopez, A.D. and Murray, C.J, "Global and regional estimates of cancer mortality and incidence by site: II. Results for the global burden of disease 2000, BMC Cancer 2, 37, 2002.

3. Hortobagyi, G.N., de la Salazar, G.J etal."The global breast cancer burden: Variations in epidemiology and survival," Clin Breast Cancer, 6 (5), 391-401, 2005.

4. Jemal, A., Bray, F., Center, M.M., Ferlay, J., Ward, E. and Forman, D, "Global cancer statistics," CA Cancer J Clin, 61 (2), 69-90, 2011.

5. Kanaga, K.C., Nithiya, J. and Shatirah, M.F, "Awareness of breast cancer and screening procedures among Malaysian women," Asian Pacific J Cancer Prev, 12 (8), 1965-1967, 2011.

6. Salem, O.A. and Hassan, M.A, "Breast self-examination among female nurses" Rawal Med J, 32 (1), 31-33, 2007

7. Rao R.S., Nair S., Nair N.S., Kamath V.G, Acceptability and effectiveness of a breast Health awareness programme for rural women in India. Indian J Med Sci, 59, 398-402, 2005.

8. Wu, T.Y., West, M.A., Chen, Y.W. and Hergert, C, "Health beliefs and practices related to breast cancer screening in Filipino, Chinese and Asian-Indian women," Cancer Detect Prev, 30 (1), 5866, 2006.

9. World Health Organization, Breast cancer: prevention and control, 2013. http://www.who.int/cancer/detection/breas tcancer/en/print.html.
10. Dundar, P.E., Ozmen, D et al. "The knowledge and attitudes of breast selfexamination and mammography in a group of women in a rural area in western Turkey, BMC Cancer, 6, 43, 2006.

11. Parvani, Z, "Breast self-examination: Breast awareness and practices of systematic review, Professional Med J, 18, 336-339, 2011.

12. World Health Organization. National cancer control programmes: policies and Managerial guidelines. Geneva, Switzerland: WHO. 2002. 